\title{
Factors influencing the release of assayable folate from erythrocytes
}

\author{
A. OMER ${ }^{1}$ \\ Department of Therapeutics, The Royal Infirmary, Edinburgh
}

SYNOPSIS The effects of $p \mathrm{H}$, ascorbic acid, temperature, and time on folate release from whole blood haemolysates were investigated. Maximal yields of assayable folate were obtained within 10 minutes at room temperature in whole blood haemolysates prepared at $p \mathrm{H} \mathrm{3.6} \mathrm{in} \mathrm{aqueous} \mathrm{ascorbic}$ acid solution. When prepared over a period of two hours, haemolysates yielded maximal folate values within a much wider $p \mathrm{H}$ range $(3.0$ to 6.0$)$. Released folate is shown to be extremely labile between $p \mathrm{H} 4.7$ and 3.0 but the presence of ascorbic acid in a concentration of $25 \mathrm{mg} \%$ or more afforded complete protection. The possible nature of the plasma folate-releasing factor and the significance of these findings in relation to the laboratory estimation of whole blood folate are discussed.

Wolff, Drouet, and Karlin (1949) showed that human plasma contains a factor that is capable of releasing assayable folate from extracts of yeast incubated at $37^{\circ} \mathrm{C}$ and at $p \mathrm{H} 4 \cdot 5$. Toennies, Usdin, and Phillips (1956) demonstrated the importance of this factor for the release of the $L$. casei active material from erythrocytes. These workers found that the folate yield from erythrocytes is markedly enhanced by the incubation of whole blood at $37^{\circ} \mathrm{C}$ in phosphate buffer $p \mathrm{H} \mathrm{6.0} \mathrm{to} 6 \cdot 1$ before the precipitation of proteins by autoclaving. These conditions for 'maximal' folate release have since been adopted by most workers when estimating whole blood folate (Hansen and Nyström, 1961 ; Grossowicz, Mandelbaum-Shavit, Davidoff, and Aronovitch, 1962; Cooper and Lowenstein, 1964; Grzesiukowicz, Jennison, and Gowenlock, 1965). Recently, however, Hoff brand, Newcombe, and Mollin (1966) found that incubation at $37^{\circ} \mathrm{C}$ does not increase the folate content of whole blood haemolysates when prepared in $1 \mathrm{~g} \%$ ascorbic acid solution. Under these conditions the 'maximal' amount of folate is released at $p \mathrm{H} \mathrm{3.6}$ to 3.8. This is at variance with the original observations of Toennies, Frank, and Gallant (1953) who found that the folate yield fell almost to zero at $p \mathrm{H} 4.0$ and was maximal within a narrow $p \mathrm{H}$ range around $5 \cdot 7$, and so led Toennies et al in later work (1956) to consider $p \mathrm{H} 6.0$ as optimal for plasma factor action.

${ }^{1}$ Present Address: Department of Pathology, Faculty of Medicine, P.O. Box 102, Khartoum, Sudan.

Received for publication 2 July 1968.
In view of these contradictory data, experiments were carried out to investigate some of the factors affecting the release of assayable folate from erythrocytes. This paper reports on the influence of ascorbic acid, $p \mathrm{H}$, and temperature on such release.

\section{MATERIALS AND METHODS}

The study was performed on blood samples obtained from healthy subjects with a normal peripheral blood picture.

Blood from each subject, 40 to $60 \mathrm{ml}$, was transferred into sterile heparinized Universal containers, and the plasma was separated by immediate centrifugation for half an hour at $1,000 \mathrm{~g}$. Five $\mathrm{ml}$ of the plasma to be used for plasma folate estimation was stored at $-20^{\circ} \mathrm{C}$ after the addition of $10 \mathrm{mg}$ of dry ascorbic acid per $\mathrm{ml}$. The remainder was recombined with enough of the red cells to give a packed cell volume (PCV) of $30 \% \pm 2 \%$ in all experiments. Any subsequent dilutions were carried out with deionized water.

Haemolysis of whole blood in water or ascorbic acid solution for 10 minutes at room temperature, followed by freezing for one hour at $-20^{\circ} \%$ and thawing for a further hour at room temperature, was adopted as a standard procedure for releasing assayable folate from erythrocytes in experiments 1,2 , and 3 . Haemolysis at particular $p \mathrm{H}$ values was achieved by adding appropriate quantities of $\mathrm{N} / \mathrm{IHCl}$ of $\mathrm{N} / \mathrm{INaOH}$ to the haemolysing fluids before adding blood.

The folate content of whole blood was extracted by combining $2 \mathrm{ml}$ aliquots of haemolysates with $18 \mathrm{ml}$ of $0 \cdot 1 \mathrm{M}$ phosphate buffer $(p \mathrm{H} 6.0$ to 6.1$)$ with ascorbic acid at a final concentration of $200 \mathrm{mg} \%$ and precipitating the proteins by autoclaving at $15 \mathrm{lb} / \mathrm{sq}$ in. for five minutes. 
The clear extracts, separated by centrifugation and filtration, were stored at $-20^{\circ} \mathrm{C}$ until assayed at a final dilution of $1 / 600$ to $1 / 800$.

The Lactobacillus casei activity of whole blood and plasma extracts was estimated by the method of Waters and Mollin (1961), except that autoclaved ascorbate phosphate buffer was added to standard tubes.

CALCULATION of RESUlTs Whole blood folate values were calculated in $\mathrm{m} \mu \mathrm{g} / \mathrm{ml}$ of packed cells, using the formula:

$\frac{\text { Whole blood folate }- \text { plasma folate } \times\left(1-\frac{\text { PCV }}{100}\right)}{\frac{\text { PCV }}{100}}$

Comparisons of the amounts of folate released under differing conditions were sometimes carried out on the same blood specimen (experiments 1, 2, and 4). To facilitate analysis of the results, blood folate values in $\mathrm{m} \mu \mathrm{g} / \mathrm{ml}$ of packed cells were expressed in these experiments as percentages of the arbitrary optimum folate yield. This is defined as the amount of folate released, in $\mathrm{m} \mu \mathrm{g} / \mathrm{ml}$ of packed cells, when blood is haemolysed at a dilution of $1: 10 \mathrm{in} 1 \mathrm{~g} \%$ aqueous ascorbic acid solution and the haemolysate is incubated for 90 minutes at $37^{\circ} \mathrm{C}$. Such a haemolysate was therefore prepared from each blood specimen investigated in each experiment.

The $p \mathrm{H}$ determinations were carried out with a Beckmann model $72 p \mathrm{H}$ meter.

\section{RESULTS}

EFFECT OF HAEMOLYSATE ASCORBIC ACID CONCENTRATION ON FOLATE RELEASE This was studied by preparing serial haemolysates from each of nine blood specimens at dilutions of $1: 5$ and $1: 10$ in aqueous ascorbic acid solutions containing 0 to $1 \mathrm{~g} \%$. The results are shown in Table $\mathrm{I}$ which relates the mean haemolysate $p H$ value and the mean percentage folate yield to the corresponding ascorbic acid concentration. Table I shows that at both dilutions there is an increasing folate yield witer increasing ascorbic acid concentration. The increase in folate yield is related to the $p H$ produced by added ascorbic acid and not to its concentration ie, at similar $p \mathrm{H}$ values, folate yield is similaf irrespective of ascorbic acid concentration. The highest folate values are observed at $p H 5.8$ or less?

EFFECT OF $p$ H ON FOLATE RELEASE Figure 1 relates yield to $\mathrm{pH}$ in a series of haemolysates prepared from five blood specimens in water containing no ascorbigu acid. There is nearly $100 \%$ folate yield over the $p$ range of 4.8 to 6.0 , almost no assayable folate at pH 3.0, and at $p \mathrm{H} 9 \cdot 0$ the folate yield ranges from $25 \%$ to $39 \%$.

Figure 2 illustrates the relationship of folate yield to $p H$ when haemolysis was carried out if $25 \mathrm{mg} \%$ aqueous ascorbic acid solutions using the same blood specimens as above. The $p H$ for maximat folate release is now $3 \cdot 0$ to $6 \cdot 0$.

pH STABILITY OF RELEASED FOLATE Figure 3 show $\vec{b}$ the recovery of assayable folate at different $p$ values. In this experiment a large volume of whole blood haemolysate was prepared without ascorbie acid at $p H \mathbf{H} \cdot 2$ and subjected to the standard pros cedures for 'maximal' folate release. Aliquots of the haemolysate were then readjusted within $\mathbf{p H}$ range्s 3.0 to 11.0 . In one aliquot $25 \mathrm{mg} \%$ ascorbic aci\& was added before reducing the $p \mathrm{H}$ to $3 \cdot 5$. Folate recovery was expressed as a percentage of the folate content of the original haemolysate. Figure 3 shows that folate recovery falls at $\mathrm{pH}$ values below $5 \cdot 2$. unless $25 \mathrm{mg} \%$ ascorbic acid is added to haemo lysates before the $p \mathbf{H}$ reduction. This extreme lability of assayable folate and its complete protec 3 . tion by ascorbic acid explains the different $p H$ ranges observed for maximal folate release in Figures and 2.

TABLE I

EFFECT OF ASCORBIC ACID CONCENTRATION ON HAEMOLYSATE $p$ H AND PERCENTAGE FOLATE YIELD ${ }^{1}$

Blood Dilution 1:5

\begin{tabular}{llll}
\hline $\begin{array}{l}\text { Haemolysate Ascorbic } \\
\begin{array}{l}\text { Acid Concentration } \\
(m g \%)\end{array}\end{array}$ & $\begin{array}{l}\text { Mean } \\
\text { Haemolysate } \\
\text { pH }\end{array}$ & $\begin{array}{l}\text { Mean } \\
\text { Folate } \\
\text { Yield (\%) }\end{array}$ & $\begin{array}{c}\text { S } \\
\pm\end{array}$ \\
\hline & & & 87 \\
20 & $7 \cdot 47$ & 47 & $9 \cdot 2$ \\
40 & $7 \cdot 35$ & 53 & $8 \cdot 7$ \\
80 & $7 \cdot 25$ & $63^{2}$ & $5 \cdot 6$ \\
200 & 6.92 & $95^{3}$ & $4 \cdot 3$ \\
400 & $5 \cdot 84^{3}$ & 98 & $3 \cdot 4$ \\
600 & $4 \cdot 73$ & 97 & $2 \cdot 9$ \\
800 & $4 \cdot 41$ & 98 & 1.9
\end{tabular}

Blood Dilution 1:10

Haemolysate Ascorbic Acid Concentration ( $m g$ \%)

$\begin{array}{ll}\text { Mean } & \text { Mean } \\ \text { Haemolysate } & \text { Folate } \\ \text { pH } & \text { Yield (\%) }\end{array}$

$\begin{array}{ll}\text { Haemolysate } & \text { Folate } \\ \mathrm{pH} & \text { Yield }(\%)\end{array}$

$7 \cdot 29$
$6 \cdot 87^{2}$
$6 \cdot 63$
$5 \cdot 83^{8}$
$4 \cdot 48$
$4 \cdot 13$
$3 \cdot 9$
$3 \cdot 67$

40
$61^{2}$
75
$95^{3}$
95
97
99
98
$61^{2}$ 75 $95^{3}$

97

99

${ }^{1}$ The $\mathrm{pH}$ and folate values represent the means of results obtained for nine blood specimens at dilutions of $1 / 5$ and $1 / 10$.

2 and ${ }^{3}=$ similar folate values occurring at similar $p H$ values irrespective of ascorbic acid concentration or blood dilution. 


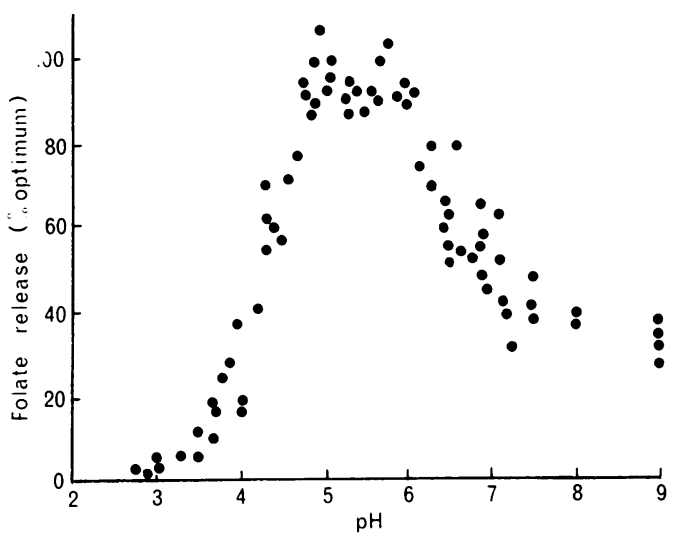

PIG. 1. Folate release related to $\mathrm{pH}$ in haemolysates prepared without ascorbic acid.

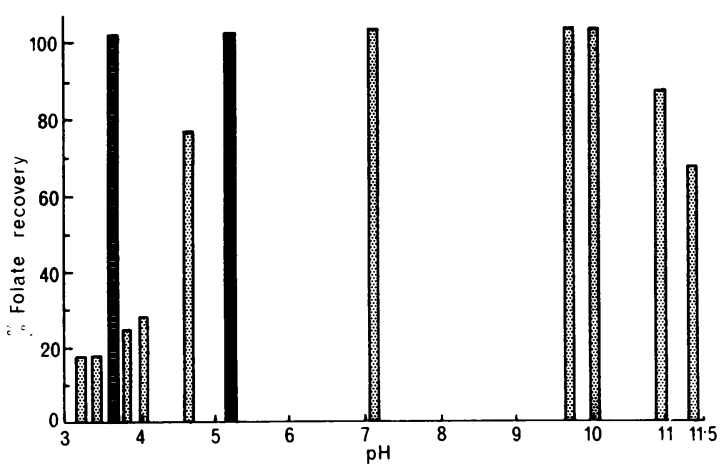

Folate remaining after readjusting the Haemolysate $\mathrm{pH}$ Original Folate content of Haemolysate

al anIIII $\mathrm{pH}$ lowered in presence of $25 \mathrm{mg} . \%$ of Ascorbic acid

FIG. 3. The percentage recovery of assayable folate determined in the absence of ascorbic acid at various $\mathrm{pH}$ values and at $\mathrm{pH} 3.6$ in the presence of $25 \mathrm{mg} \%$ ascorbic acid.

RATE OF FOLATE RELEASE AT DIFFERENT $p H$ VALUES Folate yield was determined in subsamples removed over a period of 30 minutes from haemolysates prepared at room temperature and at $\mathrm{pH} 3.6$ and 5.8 respectively. The results are shown in Table II. These show that 'maximal' levels of assayable folate are obtained within 10 minutes from the initiation of haemolysis at $p \mathbf{H ~ 3 . 6 . ~ I n ~ c o n t r a s t ~ f o l a t e ~ y i e l d ~ a t ~}$ $p \mathrm{H} 5.8$ is still suboptimal at $\mathbf{3 0}$ minutes. The degree of haemolysis was tested for and found to be complete $(100 \%)$ under both conditions within 10 minutes from the dilution of blood.

FOLATE RELEASE AFTER FREEZING AND THAWING COMPARED TO THAT AT $4^{\circ} \mathrm{C}$ Table III compares the

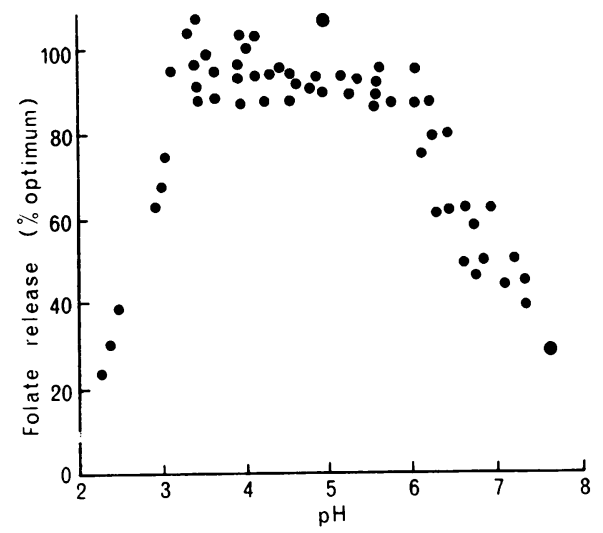

FIG. 2. Folate release related to $\mathrm{pH}$ in haemolysates prepared in $25 \mathrm{mg} \%$ aqueous ascorbic acid solution.

TABLE II

RATE OF FOLATE RELEASE AT ROOM TEMPERATURE IN ASCORBIC ACID CONTAINING HAEMOLYSATES PREPARED FROM TWO BLOOD SAMPLES

Blood Specimen

\begin{tabular}{lllll}
\hline No. 1 & & $\frac{N o .2}{2}$ & \\
\hline$p \mathrm{H}$ & & $p \mathrm{H}$ & \\
\hline 3.6 & 5.8 & 3.6 & 5.8
\end{tabular}

Incubation Time at Room Temperature

Percentage Folate Release (min)

$\begin{array}{rrrrr}5 & 52 & 34 & 62 & 25 \\ 10 & 99 & 47 & 102 & 31 \\ 15 & 97 & 66 & 95 & 38 \\ 30 & 100 & 78 & 96 & 47\end{array}$

mean folate values of three blood specimens prepared by the two methods at different $p \mathrm{H}$ values. At four $p \mathrm{H}$ values, haemolysates prepared at $4^{\circ} \mathrm{C}$ gave lower folate values but the differences are not significant for the number of specimens investigated $(P<0.4>0.3)$. For haemolysates prepared by freezing and thawing, the mean folate yield between pH 5.6 and 3.6 ranges from $92 \%$ to $100 \%$ which agrees with the findings in Figure 2. All folate values are expressed as percentages of the arbitrary optimal yield (folate release in haemolysates prepared in a $\mathrm{g} \%$ ascorbic acid solution and incubated for 90 minutes at $37^{\circ} \mathrm{C}$ ).

\section{DISCUSSION}

Toennies et al $(1953,1956)$ showed that the bulk of folate resides inside erythrocytes as microbiologically inactive precursors. They demonstrated the importance of a plasma 'enzyme' for the release of $L$. case $i$ - 
TABLE III

MEAN PERCENTAGE FOLATE YIELD IN THREE BLOOD SPECIMENS AFTER INCUBATION AT $4^{\circ} \mathrm{C}$ FOR TWO HOURS COMPARED AT: DIFFERENT $p H$ VALUES TO THAT OBTAINED AFTER FREEZING AND THAWING

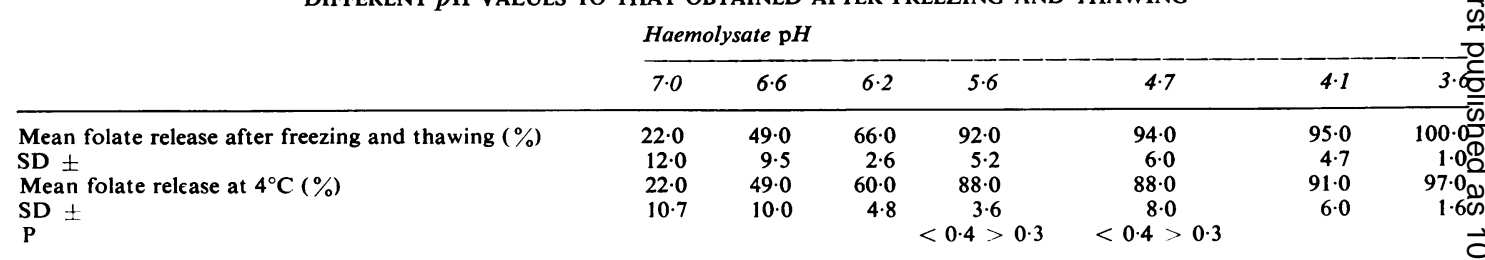

active material from these precursors and found that such a release was best attained around $p \mathrm{H} 6 \cdot 0$ and a temperature of $37^{\circ} \mathrm{C}$. The present findings, however, differ in many respects from those reported by Toennies and his colleagues, as regards conditions governing maximal folate yield in whole blood haemolysates.

Thus when whole blood haemolysates are prepared by the method described in aqueous solutions containing $25 \mathrm{mg} \%$ or more ascorbic acid, they yield their 'maximal' folate values within a wide $p \mathrm{H}$ range, namely, 3.0 to 6.0 . It is demonstrated that ascorbic acid makes no significant difference in folate yield between $p \mathrm{H} 4.8$ and 6.0. Within $p \mathrm{H} 4.7$ to $3 \cdot 0$, however, released folate becomes progressively unassayable unless ascorbic acid is present in haemolysates to exert a protective effect. This extreme lability of the $L$. case $i$-active material at low $p \mathrm{H}$ and its complete protection by ascorbic acid has not been demonstrated previously, and partly explains why Toennies et al (1953), who did not include ascorbic acid in their experiments, found that the folate yield approached zero at $p \mathrm{H} 4.0$ and was maximal around a much narrower $p \mathrm{H}$ range compared with that described in the present study.

Although the 'maximal' folate yield is between $p \mathrm{H} 3.0$ and 6.0 in haemolysates prepared over two hours by the method described, folate, when timed at shorter intervals, was found to be released much more rapidly at the lower side of this $p \mathrm{H}$ range. Thus in two blood specimens investigated, the amounts released after 10 minutes at room temperature were $99 \%$, and $102 \%$ of the arbitrary optimal yield at pH 3.6 compared with $47 \%$ and $31 \%$ respectively at $p \mathrm{H} \mathrm{5.8} \mathrm{(Table} \mathrm{II).} \mathrm{A} \mathrm{fall} \mathrm{in} p \mathrm{H}$ alone, in the absence of plasma, was not associated with the release of assayable folate from erythrocytes. This means that the low $p \mathrm{H}$ enhances folate yield by potentiating the 'enzymatic' action of plasma on the erythrocyte folate precursor which in turn indicates that low $p H$ values, $i e$, in the region of $3 \cdot 6$, are better for plasma factor action than those around 5.8. Folate is present inside the erythrocyte as conjugates of $\mathrm{N}^{5}$-methyltetrahydrofolic acid (Noronha and Aboobaker, 1963) which are bound to an intracellular protein (Iwai,
Luttner, and Toennies, 1964). It is possible that the fall in $p \mathrm{H}$ facilitates folate yield by breaking oro denaturing the binding sites of the substrate insiden the cell and so exposing it to enzymatic action. Tho enzyme involved has to be a plasma 'peptidase capable of hydrolysing glutamyl peptide bonds and exhibiting optimal activity at a low $p \mathrm{H}$. Such enzymes are usually present in biological material as precursors requiring activation before they cans function. A notable example of this is the auto catalytic conversion of pepsinogen to pepsin below pH 5.0. Pepsinogen is known to occur in humang plasma. Pepsin is generally recognized to have an optimum $p \mathrm{H}$ around $2 \cdot 0$. However, depending on the nature of peptide bonds of the substrate, itss optimum $p H$ may be higher (Bovey and Yanari $\frac{\partial}{\bar{D}}$ 1960). Investigations are being carried out with special reference as to whether plasma pepsinogen is 8 involved in the release of assayable folate at low $p \mathrm{H}$.

Enzyme activity is recognized to extend over as limited $p \mathrm{H}$ range. In view of the fact that under the present experimental conditions the 'maximal' folate. is yielded over a wide $p \mathrm{H}$ range (3.0 to 6.0), and also? because of the demonstrated variable rate of folate release at two $p \mathrm{H}$ points within this range, the possibility of more than one plasma 'enzyme', eache with different kinetics and $p \mathbf{H}$ requirements, cannot be excluded. The multiplicity of the plasma factors had already been suggested by Toennies and Phillips (1959) but their results were based on folate yield in incubation mixtures at $p \mathrm{H} 6 \cdot 0$. The elucidation of this problem depends upon purer forms of the substrate and enzymes to investigates the kinetics at different values for $p \mathrm{H}$.

It seems that the enzymatic release of assayable folate from erythrocytes is predominantly $p \mathrm{H}$ dependent and that changes in temperature have noo significant effect on folate yield over the period of two hours adopted. Thus in all experiments in the present work folate yield has been assessed withouf incubating haemolysates at $37^{\circ} \mathrm{C}$ but the results have been related as percentages to folate release from haemolysates prepared in $1 \mathrm{~g} \%$ ascorbic acid solution incubated at $37^{\circ} \mathrm{C}$ for 90 minutes (the arbitrarys 
optimal yield). The occurrence, therefore, at a favourable $p \mathrm{H}$ of 'maximal' folate yields in these experiments indicates that a temperature of $37^{\circ} \mathrm{C}$ is not important for plasma factor action over the time adopted. Even when haemolysates are prepared at $4^{\circ} \mathrm{C}$, the folate yield at any particular $p \mathrm{H}$ value is not significantly different from that obtained by freezing and thawing. There is no proof in the present work that the mechanical disruption of red cells by freezing and thawing is important for folate release. This procedure was adopted in preference to others, however, to ensure adequate haemolysis (an important requirement for the availability of substrate) under various conditions, $e g$, when using packed cells or preparing haemolysates at a high $p \mathrm{H}$.

The finding in the present study of rapid 'maximal' folate yield (within 10 minutes) at room temperature in haemolysates prepared in ascorbic acid solutions at a final $p \mathrm{H}$ of 3.6 provides a convenient method for the laboratory estimation of whole blood folate in clinical material. Thus folate release preparations are simple to set up, and the method dispenses with the 90 minutes' incubation periods adopted in other methods. These recommended conditions are provided by using the method of Hoffbrand et al (1966) who prepare haemolysates in $1 \mathrm{~g} \%$ aqueous ascorbic acid solution. When viewed in the light of the present results it will be seen that ascorbic acid at such a concentration, in addition to protecting released folate, drops the haemolysate $p \mathrm{H}$ to the desired value of 3.6 (see Table I). Further, these authors have shown that the folate content of such haemolysates was not affected by storage for up to five months at $-20^{\circ} \mathrm{C}$. This method is, therefore, strongly recommended for the laboratory estimation of whole blood folate.

It is a pleasure to thank Professor R. H. Girdwood of the Department of Therapeutics, University of Edinburgh, and Dr S. H. Davies, consultant haematologist, South Eastern Regional Hospital Board (Scotland), for their indispensable help during the course of this work. I am very grateful also to $\mathrm{Dr}$ N. D. C. Finlayson and $\mathrm{Dr}$ D. J. C. Shearman of the Department of Therapeutics, and Dr N. C. Allan, consultant haematologist, Western General Hospital, Edinburgh, for their criticism and help in writing this paper.

\section{REFERENCES}

Bovey, F. A., and Yanari, S. S. (1960). Pepsin. In The Enzymes, 2nd ed., edited by P. D. Bayer, H. Lardy, and K. Myrbäcks, Vol. 4, p. 63. Academic Press, New York and London.

Cooper, B. A., and Lowenstein, L. (1964). Blood, 24, 502.

Grossowicz, N., Mandelbaum-Shavit, F., Davidoff, R., and Aronovitch, J. (1962). Ibid., 20, 609.

Grzesiukowicz, H., Jennison, R. F., and Gowenlock, A. H. (1965). J. clin. Path., 18, 599.

Hansen, H. A., and Nyström, B. (1961). Geront. clin. (Basel), 3, 173. Hoff brand, A. V., Newcombe, B. F. A., and Mollin, D. L. (1966). J. clin. Path., 19, 17.

Iwai, K., Luttner, P. M., and Toennies, G. (1964). J. biol. Chem., 239, 2365.

Mollin, D. L., and Hoff brand, A. V. (1965). In Vitamin $B_{12}$ and Folic Acid (Scand. J. Haemat., series Haematologica, 3). p. 1. Munksgaard, Copenhagen.

Noronha, J. M., and Aboobaker, V. S. (1963). Arch. Biochem., 101, 445.

Toennies, G., Frank, H. G., and Gallant, D. L. (1953). J. biol. Chem., 200, 23.

—, and Phillips, P. M. (1959). Ibid., 234, 2369.

$\longrightarrow$, Usdin, E., and Phillips, P. M. (1956). Ibid., 221, 855.

Waters, A. H., and Mollin, D. L. (1961). J. clin. Path., 14, 335.

Wolff, R., Drouet, L., and Karlin, R. (1949). Science, 109, 612. 